\title{
Capacitive deionization (CDI) for desalisation using carbon aerogel electrodes
}

- Le Khac Duyen

- Pham Quoc Nghiep

- Le Anh Kien

Institute for Tropicalisation and Environment, ITE, Ho Chi Minh City, Vietnam

(Manuscript Received on July, 2016, Manuscript Revised on September, 2016)

\begin{abstract}
Capacitive deionization (CDI) is an

carbon aerogel electrodes were investigated for electrochemical water treatment process that holds the promise of not only being a commercially viable alternative for treating water but for saving energy as well. Carbon aerogel electrodes for CDI process with high specific surface area $\left(779.04 \mathrm{~m}^{2} / \mathrm{g}\right)$ and nanopore $(2-90 \mathrm{~nm})$ have been prepared via pyrolyzing $R F$ organic aerogel at $800 o \mathrm{C}$ in nitrogen atmosphere. The CDI characteristics of

Keywords: Capacitive deionization, carbon electrosorption.

\section{INTRODUCTION}

Capacitive deionization (CDI) is a technology for removing ionic materials from aqueous solution using an electrostatic adsorption reaction on the electric double layer (EDL) created on the electrode surface interface when a potential is applied on porous carbon electrodes $[1,2]$. The technique is mainly applicable for brackish water and offers advantage of easy regeneration, low voltage, and ambient operational conditions. Salty water is

the $\mathrm{NaCl}$ absorption into a CDI cell at variation conditions. Experiments data showed that the maximum $\mathrm{NaCl}$ removal capacity was 21.41 $\mathrm{mg} / \mathrm{g}$ in $500 \mathrm{mg} / \mathrm{L} \mathrm{NaCl}$ solution, higher than for other carbon-based materials in the literature. It was evaluated that the CDI process using carbon aerogel electrodes promising to be an effective technology for desalination.

aerogel, aerogel electrodes, desalination, passed through the electrode surface with an applied charge. Cations and anions are drawn toward the cathode and anode, respectively. Salts from water are removed by the electrosorption of ions on the porous surface of electrodes [3]. After the electrode becomes saturated, it can easily be regenerated by cancelling or changing the electrical potential of the electrodes, the regeneration of the electrode is not only very simple, but is also recognized as an environmentally friendly process $[4,5]$.
\end{abstract}


Many studies have applied various porous carbon materials for CDI process including activated carbon $[6,7]$, activated carbon fibers $[8,9]$, ordered mesoporous carbons [10], carbon aerogel [11, 12], carbon nanotube and graphene $[13,14]$. Carbon aerogels, a porous material that features high specific surface area, low density, good electrical conductivity and high chemical stability, seem to be a promising porous materials for CDI technology. In the early 1990's, Farmer et al. developed carbon aerogel materials, with specific surface area of 600-800 $\mathrm{m}^{2} / \mathrm{g}$, using in a capacitive deionization process for removing mixed ionic solutions $[3,15]$. The electrosorption of several cations and anions $\left(\mathrm{Na}^{+}, \mathrm{K}^{+}, \mathrm{Mg}^{2+}, \mathrm{Rb}^{+}, \mathrm{Br}^{-}, \mathrm{Cl}^{-}, \mathrm{SO}_{4}{ }^{2-}, \mathrm{NO}_{3}{ }^{-}\right)$from natural river water was studied in the research of Gabelich et al. [16] for carbon aerogel electrodes with a specific surface area of 400$590 \mathrm{~m}^{2} / \mathrm{g}$ and average pore sizes in range of 4-9 $\mathrm{nm}$. It was found that monovalent ions with a smaller (hydrated) ion size were preferentially electrosorbed by $\mathrm{CA}$ electrodes. Xu et al. have used carbon aerogel electrodes to show the successful deionization of brackish wastewater [4]. Considering the low mechanical stability of $\mathrm{CA}$ as a result of the very low density and large porosity, paste rolling of CA with silica gel was studied by Yang et al. [17] as a method to improve the mechanical properties. Variation of carbon to silica mass ratios were investigated and slight effect on performance of the CDI process was observed when adding the silica gel. Kohli et al. [18] were also studied the electrodes synthesized using mesoporous carbon aerogel, microporous-activated carbon, and different combinations of the two for capacitive deionization application. The experiments data indicated composite electrodes showed fast absorption and desorption and higher salt removal efficiency.

In this work, carbon aerogels were generally synthesized by pyrolysis of resorcinolformaldehyde organic aerogel obtained from ambient drying. Carbon aerogel electrodes for CDI process were developed by a coating method using polyvinyl alcohol (PVA) as a binder and evaluated their properties. The CDI experiments using carbon aerogel electrodes were fabricated and their CDI characteristics on $\mathrm{NaCl}$ solution were examined. The operational conditions of CDI systems were investigated for maximizing ion absorption.

\section{EXPERIMENTAL}

\subsection{Fabrication of carbon aerogel electrodes}

\subsubsection{Preparation of carbon aerogels}

Carbon aerogel (CA) was derived from pyrolysis of a resorcinol-formaldehyde (RF) aerogel [19]. The molar ratio of formaldehyde (F) to resorcinol (R) was held at a constant value of 2 . They were dissolved in distilled water with $\mathrm{Na}_{2} \mathrm{CO}_{3}$ as a base catalyst, the mass percentage of the reactants in solution was set at $\mathrm{RF}=40 \%$, and the molar ratio of resorcinol to catalyst $(\mathrm{C})$ was set at $\mathrm{R} / \mathrm{C}=1000$. Sol-gel polymerization of the mixture was carried out in plastic moulds by holding the mixture at room temperature for $24 \mathrm{~h}$, at $50^{\circ} \mathrm{C}$ for $24 \mathrm{~h}$, and at $80^{\circ} \mathrm{C}$ for $72 \mathrm{~h}$ to obtain RF wet gels. The aqueous gels were then exchanged with acetone for 3 days. Subsequently, RF organic aerogels were prepared by directly drying RF wet gels at ambient temperature and pressure for 5 days. Carbon aerogels for the CDI process were synthesized via pyrolyzing RF organic aerogels at $800^{\circ} \mathrm{C}$ in a continuous nitrogen atmosphere, flowing at a rate of $400 \mathrm{~mL} / \mathrm{min}$ for $3 \mathrm{~h}$. Carbon

Trang 156 
aerogels were further activated at $800^{\circ} \mathrm{C}$ for $2 \mathrm{~h}$ in a flow of $\mathrm{CO}_{2}$ to remove residual organics and promote its properties.

\subsubsection{Prepare of carbon aerogel electrodes}

Carbon aerogel electrodes for CDI process were prepared by a coating method as follows. Carbon aerogel was grinded into powder and it was cast into electrode using polyvinyl alcohol (PVA) as a binder. The amount of polymer binder was controlled to achieve a solid content of 15\% after drying. Carbon aerogel and PVA were mixed in distilled water, and the mixture was then pressed onto an $\mathrm{Al}$ foil (as a current collector). The carbon coated Al foil was then dried under ambient conditions for $48 \mathrm{~h}$, and punched in required size as electrodes. The apparent surface area of the electrodes was 81 $\mathrm{cm}^{2}$ and the thickness was about $2 \mathrm{~mm}$.

\subsection{Characterization methods}

In order to investigate the microstructure of carbon aerogels, the pristine samples were characterized by scanning electron microscopy using a HITACHI S-4800 microscope and Xray diffraction using a Bruker D8 Advance diffractometer with $\mathrm{Cu}-\mathrm{K} \alpha$ radiation $(\lambda=1.54060 \AA)$ operated at the voltage and current values of $40 \mathrm{kV}$ and $40 \mathrm{~mA}$ respectively for the $2 \theta$ values in the range $5-70^{\circ}$ at a scan speed of $1.2 \% \mathrm{~min}$. Specific surface area and pore-size distribution of samples were characterized by analysis of nitrogen absorption-desorption isotherms measured by ASAP 2020 analyzer (Micrometrics Instruments Corp.). Brunauer-Emmett-Teller (BET) method was used for total surface area measurements, and t-plot method was used for estimating mesopore surface area. Pore-size distribution was obtained by the Barret-Joyner-Halenda

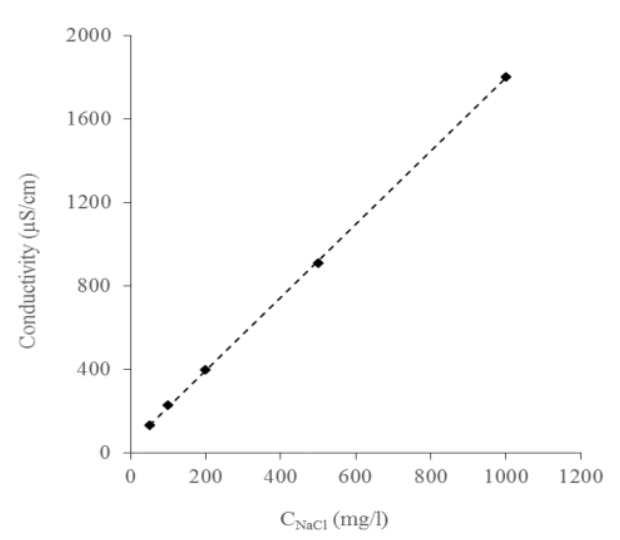

Figure 1. Calibration curve for ionic conductivity versus $\mathrm{NaCl}$ concentration.

(BJH) method from desorption branch of the isotherms. Total pore-volume was calculated from the adsorbed volume of nitrogen at $\mathrm{P} / \mathrm{P} 0=0.99$ (saturation pressure).

\subsection{Capacitive deionization experiments}

Measurement the adsorption of ions on electrodes, single-pass experiments were conducted in a cell with a dimension of $100 \mathrm{~mm}$ (long) $\times 6 \mathrm{~mm}$ (width) $\times 100 \mathrm{~mm}$ (high). The electrodes were placed face to face at both sides of a spacer with $2 \mathrm{~mm}$ and connected with a DC power supply. Water was fed from a storage vessel and the salinity (conductivity) of the water leaving the cell was measured directly at the exit of the cell. The change in the conductivity of $\mathrm{NaCl}$ solution was monitored online using an ion conductivity meter (type EC500, EXTECH). Electrosorption capacity of the carbon was determined from the change in conductivity of the salt solution using a calibration curve (Figure 1), and salt uptake was then divided by the total carbon electrode mass. Total carbon used in each experiment with a pair of carbon electrodes was 4.00 grams.

Using this calibration curve, we have (1): 
Cond. $=46.683+1.7529 \mathrm{C}_{\mathrm{NaCl}}$

where Cond. is the conductivity, and $\mathrm{C}_{\mathrm{NaCl}}$ is the $\mathrm{NaCl}$ concentration.

\section{RESULTS AND DISCUSSION}

\subsection{Physical characteristics}

Figure 2 showed the morphology of carbon aerogel samples with and without activation. The morphologies of CA particles were found to be nearly spherical in shape. CA particles were randomly crosslinked with each other, forming a continuous three-dimensional web structure with nano-sized primary particles more or less fused. The particles size of the CA was in the range of about $40-50 \mathrm{~nm}$, similar to the nanostructures of monolithic $\mathrm{CA}$ reported by $\mathrm{Wu}$ et al. [20]. The CA prepared in this work have the nano-particle structures typical of the samples prepared with the $\mathrm{CO}_{2}$ supercritical drying technique in the studies of Al-Muhtaseb et al. and Qin et al. [21, 22]. Additionally, the particles size of the CA was hardly affected by activation under $\mathrm{CO}_{2}$ flow; Figure $2 \mathrm{~b}$ indicated that the particles size was decreased into 20-30 $\mathrm{nm}$ because of the reaction of $\mathrm{CO}_{2}$ with carbon network and the abrasion of carbon structure during activation.

The XRD diagram of the synthesized CA samples were shown in Figure 3. It presented two large peaks at about $2 \theta=24^{\circ}$ and $44^{\circ}$, similar to the diffraction peaks of $\mathrm{C}(002)$ and $\mathrm{C}(101)$ and it was in agreement with the literature data [23].
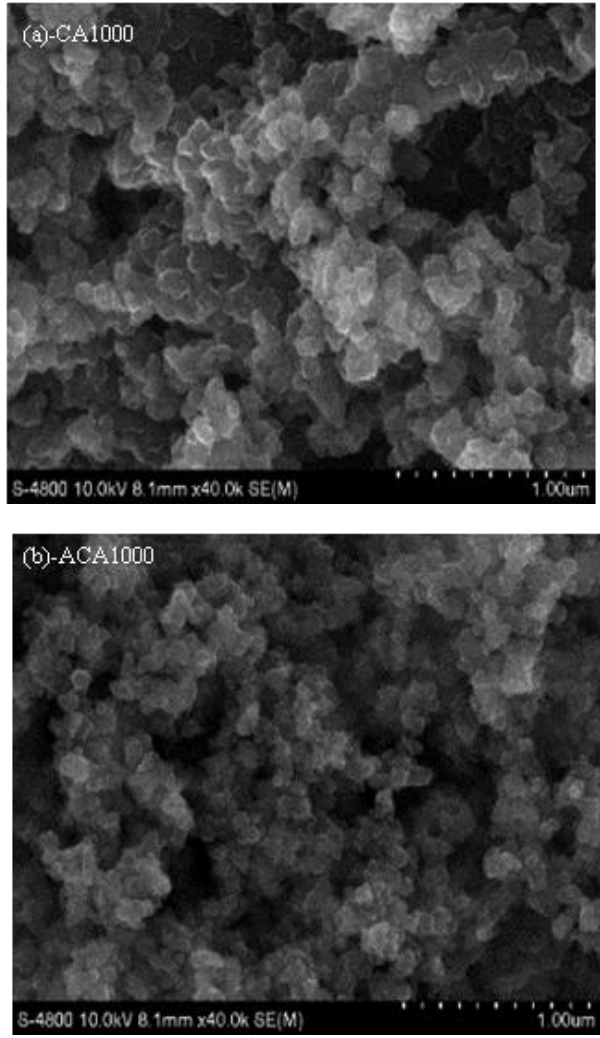

Figure 2. SEM photographs of aerogel samples. (a) carbon aerogel (CA1000) and (b) activated carbon aerogel (ACA1000).

The first peak indicated that CA samples contained a proportion of highly disordered materials in the form of amorphous carbon. In addition, the samples also contained some graphite-like structures (crystalline carbon) indicated by the presence of a clear (002) band at $\sim 24^{\circ}$ and (101) weak band at $\sim 44^{\circ}$. These observations suggested that the crystallites in all the CA samples have intermediate structures between graphite and amorphous state called turbostratic structure or random layer lattice structure.For CDI electrode materials, the specific surface area and pore size distribution were two important determinants for absorption capacity. Larger specific surface area means 
more absorption sites, leading to higher removal capacity. In our study, the pore structure of carbon aerogel and carbon aerogel electrode were characterized by nitrogen adsorption at $77 \mathrm{~K}$. Figure 4, along with the main textural parameters summarized in Table 1 , showed the nitrogen adsorption-desorption isotherm and pore size distribution of CA and CA-PVA15 electrode. The isotherm of CA and CA-PVA15 electrode has been observed to be of Type IIb following the IUPAC classification, indicating multilayer absorption on the surface of the electrode. This type of isotherm was characteristic of microporous and macroporous adsorbents. The BET specific surface area of carbon aerogel and electrode were calculated to be 779.06 and $399.41 \mathrm{~m}^{2} / \mathrm{g}$, respectively. The pore-diameter was distributed in range of 7-28 $\AA$ for both carbon aerogel and CA-PVA15 electrode, similar to the study of Seo et al. and Yang et al. [24, 25]. There were several peaks of pore size distribution indicated the macropores in the CA-PVA15 electrode, which diameter was in range of 30-90 $\mathrm{nm}$, leading to decrease specific surface area of prepared electrode.

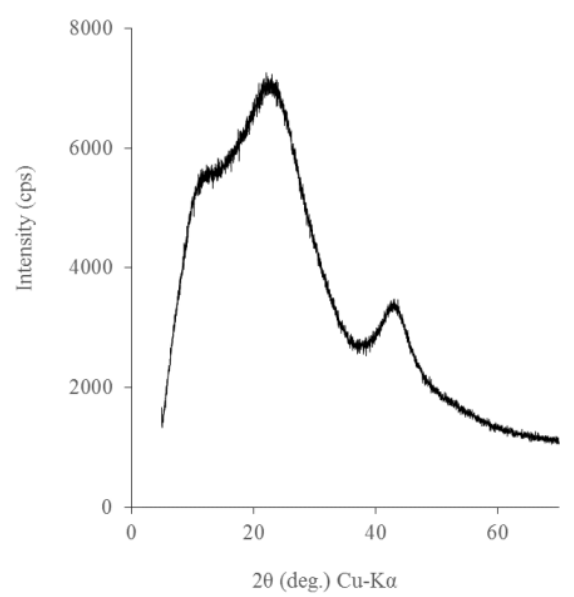

Figure 3. X-Ray diffraction pattern of carbon aerogel (CA1000).
The results of nitrogen absorption showed that surface area of carbon aerogel electrodes could be sufficiently used for CDI process.

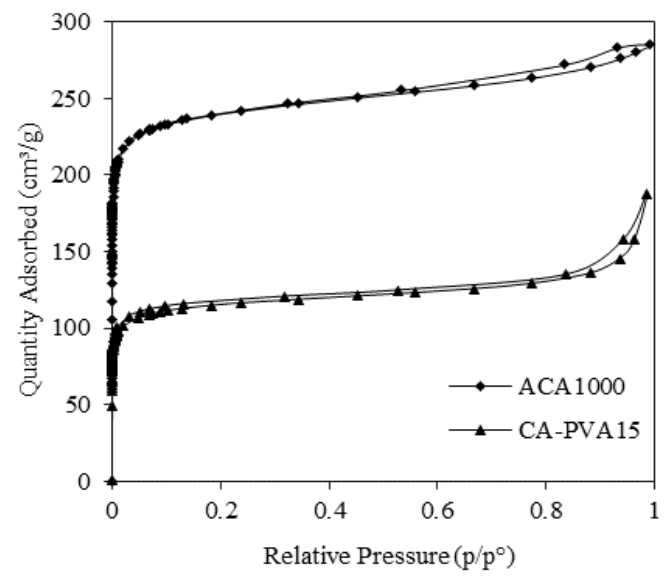

(a)

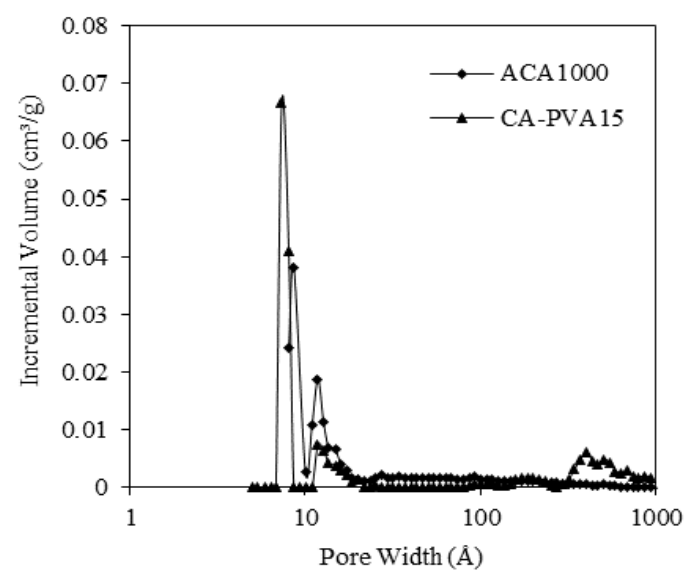

(b)

Figure 4. Nitrogen adsorption-desorption isotherm (a) and pore size distribution (b) of CA and CAPVA15 electrode. 
Table 1. Porous properties of carbon aerogels and carbon aerogel electrodes.

\begin{tabular}{|l|l|l|}
\hline Properties & Carbon aerogel & Carbon aerogel electrode \\
\hline Density $\left(\mathrm{g} / \mathrm{cm}^{3}\right)$ & $0.150-0.510$ & $0.238-0.256$ \\
\hline $\mathrm{S}_{\text {BET }}\left(\mathrm{m}^{2} / \mathrm{g}\right)$ & 779.06 & 399.41 \\
\hline Average pore size $(\AA)$ & 22.24 & 24.42 \\
\hline Median pore width $(\AA)$ & 6.11 & 9.47 \\
\hline Average particle size $(\AA)$ & 77.02 & 150.22 \\
\hline $\mathrm{V}_{\text {total }}\left(\mathrm{cm}^{3} / \mathrm{g}\right)$ & 0.4408 & 0.2896 \\
\hline $\mathrm{V}_{\text {mic }}\left(\mathrm{cm}^{3} / \mathrm{g}\right)$ & 0.3173 & 0.1371 \\
\hline $\mathrm{V}_{\text {mes }}\left(\mathrm{cm}^{3} / \mathrm{g}\right)$ & 0.0547 & 0.0453 \\
\hline $\mathrm{V}_{\text {mac }}\left(\mathrm{cm}^{3} / \mathrm{g}\right)$ & 0.0688 & 0.1072 \\
\hline $\mathrm{V}_{\text {mic }}(\%)$ & 71.98 & 47.34 \\
\hline $\mathrm{V}_{\text {mes }}(\%)$ & 12.40 & 15.64 \\
\hline $\mathrm{V}_{\text {mac }}(\%)$ & 15.62 & 37.02 \\
\hline
\end{tabular}

\subsection{Capacitive deionization characteristics}

The CDI performance of carbon aerogel was carried out to maximize the $\mathrm{NaCl}$ removal capacity by changing the $\mathrm{NaCl}$ concentration $(100-1000 \mathrm{mg} / \mathrm{L})$ and the volume flow rate (25$100 \mathrm{~mL} / \mathrm{min}$ ).The effect of initial $\mathrm{NaCl}$ concentration was performed at a volume flow rate of $50 \mathrm{~mL} / \mathrm{min}$ through a CDI unit cell with $4.0 \mathrm{~g}$ of carbon aerogels solution under $1.5 \mathrm{~V}$ of the applied voltage. The range of the $\mathrm{NaCl}$ concentration $\left(\mathrm{C}_{\mathrm{o}}\right)$ was changed from $100 \mathrm{mg} / \mathrm{L}$ to $1000 \mathrm{mg} / \mathrm{L}$. Figure 5 showed the conductivity drop of CDI process with carbon aerogel electrodes on various $\mathrm{NaCl}$ concentration. Table 2 showed the ion removal characteristics of carbon aerogel electrodes on CDI process at different conditions. The results showed that $\mathrm{NaCl}$ absorption on carbon aerogel electrodes increased in the range of $100-500 \mathrm{mg} / \mathrm{L}$ of $\mathrm{NaCl}$ concentration. The $\mathrm{NaCl}$ absorption on carbon aerogel electrodes was saturated about $21.41 \mathrm{mg}$ $\mathrm{NaCl}$ per $1 \mathrm{~g}$ of carbon aerogel over $500 \mathrm{mg} / \mathrm{L}$. When the initial $\mathrm{NaCl}$ concentration increased to
$1000 \mathrm{mg} / \mathrm{L}$, the removal capacity of carbon aerogel electrode was decreased to $8.23 \mathrm{mg}$ $\mathrm{NaCl}$ per $1 \mathrm{~g}$ carbon aerogel. In the solution, $\mathrm{Na}^{+}(1.16 \AA)$ and $\mathrm{Cl}^{-}(1.67 \AA)$ ions were existed at hydrated ions with hydrated radius of $\mathrm{Na}^{+}$and $\mathrm{Cl}^{-}$ions were $3.58 \AA$ and $3.31 \AA$, respectively. The hydrated ions radius affected on the electrical double layers (EDLs) of carbon aerogel electrodes, which were direct influence on the ions absorption of electrodes. At high $\mathrm{NaCl}$ concentration in solution, $1000 \mathrm{mg} / \mathrm{L}$, hydrated ions densities on surface of electrodes were high and formed the thickness EDLs. Additionally, small pore size of carbon aerogel leaded to EDL overlapping effect and the surface area of these pores cannot be used to adsorb ions [25], which was also the main reason for the small removal capacity of porous materials with high specific surface area at high concentration.

\section{Trang 160}


Table 2. Ions removal characteristics of carbon aerogel electrodes.

\begin{tabular}{|l|l|l|l|}
\hline $\begin{array}{l}\text { Initial } \\
\text { NaCl } \\
\text { con. } \\
(\mathbf{m g} / \mathbf{l})\end{array}$ & $\begin{array}{l}\text { NaCl } \\
\text { adsorption } \\
(\mathbf{m g} / \mathbf{g})\end{array}$ & $\begin{array}{l}\text { Flow } \\
\text { rate } \\
(\mathbf{m l} / \mathbf{m i n})\end{array}$ & $\begin{array}{l}\text { NaCl } \\
\text { adsorp- } \\
\text { tion } \\
(\mathbf{m g} / \mathbf{g})\end{array}$ \\
\hline 100 & 2.11 & 25 & 3.26 \\
\hline 200 & 5.87 & 50 & 8.23 \\
\hline 500 & 21.41 & 75 & 16.05 \\
\hline 1000 & 8.23 & 100 & 14.63 \\
\hline
\end{tabular}

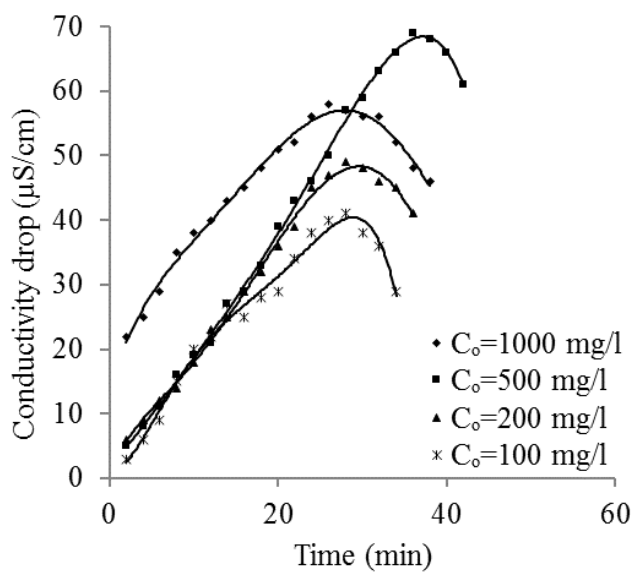

Figure 5. Effect of initial $\mathrm{NaCl}$ concentration on conductivity drop of CDI process.

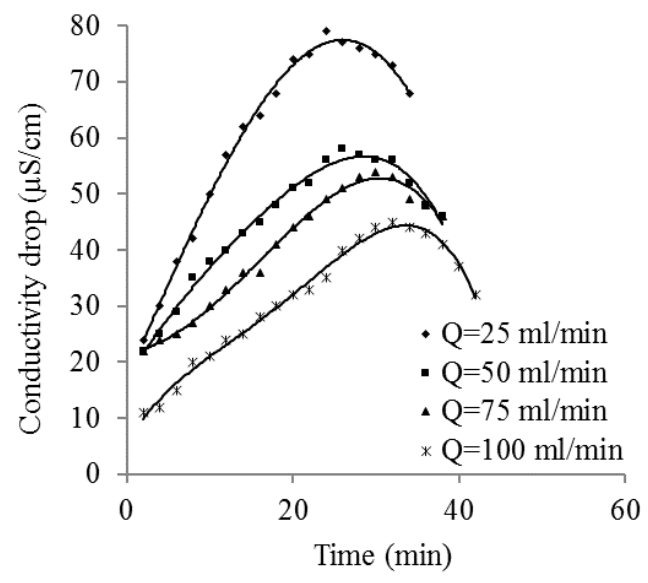

Figure 6. Effect of volume flow rate on conductivity drop of CDI process.
Figure 6 showed the effect of volume flow rate on $\mathrm{NaCl}$ removal capacity in CDI cell via the conductivity drop versus time. All experiments were performed with $1000 \mathrm{mg} / \mathrm{L}$ $\mathrm{NaCl}$ solution under $1.5 \mathrm{~V}$ of the applied voltage. The range of the volume flow rate through a CDI unit cell was changed from 25 $\mathrm{mL} / \mathrm{min}$ to $100 \mathrm{~mL} / \mathrm{min}$. It indicated that the removal capacity with volume flow rate at 75 $\mathrm{mL} / \mathrm{min}$ showed the highest result of conductivity decrease. The $\mathrm{NaCl}$ removal characteristics were summarized on Table 2 . The $\mathrm{NaCl}$ removal capacity increased as volume flow rate went up to $75 \mathrm{ml} / \mathrm{min}$, after that slight reduction while flow rate climbed to 100 $\mathrm{ml} / \mathrm{min}$. The $\mathrm{NaCl}$ absorption on carbon aerogel electrodes was reached about 16.05 and 14.63 $\mathrm{mg} \mathrm{NaCl}$ per $1 \mathrm{~g}$ carbon aerogel over 75 and 100 $\mathrm{mL} / \mathrm{min}$, respectively. The absorption of carbon aerogel electrodes increased along with the flow rate because of the corresponding increase in the linear velocity of the influent water passing through the electrode surface. It was therefore necessary to raise the adsorption rate of the electrode to enhance the processing volume with a given electrode area. An increase in the adsorption rate of ions on the electrode was required to elevate the $\mathrm{NaCl}$ removal capacity. In case of increase the flow rate to $100 \mathrm{~mL} / \mathrm{min}$, the adsorption capacity on carbon aerogel electrodes was desorbed by effect of the flow. Therefore, it was deemed necessary to reduce the time constant, which is defined as the product of the resistance of the carbon electrode and the capacitance.

\section{CONCLUSIONS}

Carbon aerogels were synthesized and used as electrodes for $\mathrm{CDI}$ of $\mathrm{NaCl}$ solution. Their monolithic continuous flexible framework, 
crystalline microstructure together with preferred macro- and micropores size distribution, result in larger effective surface area. The properties of developed carbon aerogel were $\mathrm{S}_{\mathrm{BET}}=779.06 \mathrm{~m}^{2} / \mathrm{g}$ and pore size diameter in range of 7-28 ̊. Fabricated carbon aerogel electrode increased macropores, with pore size of 300-900 $\AA$, lead to carbon aerogel electrode was sufficiently used for CDI process. The absorption tests with a CDI unit cell containing the fabricated electrode and 500 $\mathrm{mg} / \mathrm{L} \mathrm{NaCl}$ solution indicated the maximum adsorption capacity was $21.41 \mathrm{mg} / \mathrm{g}$, higher than for other carbon-based materials in the literature, which makes it a promising material for capacitive deionization. However, further experiments need to be conducted to investigate the thermal dynamics and stability of carbon aerogel for practical applications in capacitive deionization.

Acknowledgment: This research is funded by Academy of Military Science and Technology, Vietnam.

\section{Khử mặn bằng công nghệ điện dung khử ion sử dụng điện cực carbon aerogel}

- Lê Khắc Duyên

- Phạm Quốc Nghiệp

- Lê Anh Kiên

Viện Nhiệt đới môi trường, ITE

\section{TÓM TẮT}

Điện dung khư ion là phuơng pháp điện hóa xủ lý nuoóc hiện đại với nhũng ư điểm về kinh tế và năng luợng. Điện cưc carbon aerogel sư dụng trong công nghệ diện dung khử ion với diện tích bề mặt riêng cao $779.04 \mathrm{~m}^{2} / g$ và kích thước lỗ xốp nano $2-90 \mathrm{~nm}$ được chế tạo bằng phuong pháp nhiệt phân RF aerogel hũu co ơ $800^{\circ} \mathrm{C}$ trong diều kiện khí nitrogen. Các tính chất của quá trình điện dung khử ion bằng điện cưc carbon aerogel được khảo sát và đánh giá ở nhũng điều kiện khác nhau. Kết quả thực nghiệm công nghệ điện dung khư ion cho thấy khả năng hấp phụ $\mathrm{NaCl}$ của điện cực carbon aerogel đạt $21.41 \mathrm{mg} / \mathrm{g}$ với nồng độ $\mathrm{NaCl} 500$ $m g / L$, cao hơn các vật liệu điện cục khác ờ nhũng nghiên cứu trước. Thực nghiệm cho thấy công nghệ điện dung khủ ion sủ dụng điện cưc carbon aerogel có nhiều triển vọng trong công nghệ khủ mănn.

\section{Trang 162}


Tù khóa: Điện dung khử ion, carbon aerogel, điện cưc aerogel, khư mặn, hấp phư điện hóa.

\section{REFERENCES}

[1]. S. Porada, R. Zhao, A.v.d. Wal, V. Presser, P.M. Biesheuvel (2013), Review on the science and technology of water desalination by capacitive deionization, Prog.Mater. Sci. 58, 1388-1442.

[2]. Y. Oren (2008), Capacitive deionization (CDI) for desalination and water treatment - past, present and future (a review), Desalination 228, 10-29.

[3]. J.C. Farmer, D.V. Fix, G.V. Mack, R.W. Pekala, J.F. Poco (1996), Capacitive deionization of $\mathrm{NaCl}$ and $\mathrm{NaNO}_{3}$ solutions with carbon aerogel electrodes, J. Electrochem. Soc. 143, 159-169.

[4]. P. Xu, J.E. Drewes, D. Heil, G. Wang (2008), Treatment of brackish produced water using carbon aerogel-based capacitive deionization technology, Water Res. 42, 2605- 2617.

[5]. J.-A. Lim, N.-S. Park, J.-S. Park, J.-H. Choi (2009), Fabrication and characterization of a porous carbon electrode for desalination of brackish water, Desalination 238, 37-42.

[6]. J.-H. Choi (2010), Fabrication of a carbon electrode using activated carbon powder and application to the capacitive deionization process, Sep.\& Purif. Technol. 70, 362-366.

[7]. L.M. Chang, X.Y. Duan, W. Liu (2011), Preparation and electrosorption desalination performance of activated carbon electrode with titania, Desalination 270, 285-290.
[8]. Y. Bouhadana, E. Avraham, M. Noked, M. Ben-Tzion, A. Soffer, D. Aurbach (2011), Capacitive deionization of $\mathrm{NaCl}$ solutions at non-steady-state conditions: inversion functionality of the carbon electrodes, J. Phys. Chem. C 115, 16567-16573.

[9]. G. Wang, C. Pan, L. Wang, Q. Dong, C. $\mathrm{Yu}$, Z. Zhao, J. Qiu (2012), Activated carbon nanofiber webs made by electrospinning for capacitive deionization, Electrochimica Acta 69, 65-70.

[10]. C. Tsouris, R. Mayes, J. Kiggans, K. Sharma, S. Yiacoumi, D. DePaoli, S. Dai (2011), Mesoporous carbon for capacitive deionization of saline water, Environ. Sci.\&Technol. 45, 10243-10249.

[11]. G. Rasines, P. Lavela, C. Macías, M. Haro, C.O. Ania, J.L. Tirado (2012), Electrochemical response of carbon aerogel electrodes in saline water, $\mathrm{J}$. Electroanal. Chem. 671, 92-98.

[12]. J. Landon, X. Gao, B. Kulengowski, J.K. Neathery, K. Liu (2012), Impact of pore size characteristics on the electrosorption capacity of carbon xerogel electrodes for capacitive deionization, J. Electrochem. Soc. 159, A1861-A1866.

[13]. Z. Wang, B. Dou, L. Zheng, G. Zhang, Z. Liu, Z. Hao (2012), Effective desalination by capacitive deionization with functional graphene nanocomposite as novel electrode material, Desalination 299, 96102.

[14]. Z. Sui, Q. Meng, X. Zhang, R. Ma, B. Cao (2012), Green synthesis of carbon nanotube-graphene hybrid aerogels and 
their use as versatile agents for water purification, J. Mater. Chem. 22, 87678771.

[15]. J.C. Farmer, S.M. Bahowick, J.E. Harrar, D.V. Fix, R.E. Martinelli, A.K. Vu, K.L. Carroll (1997), Electrosorption of Chromium Ions on Carbon Aerogel Electrodes as a Means of Remediating Ground Water, Energy \& Fuels 11, 337347.

[16]. C.J. Gabelich, T.D. Tran, I.H.M. Suffet (2002), Electrosorption of Inorganic Salts from Aqueous Solution Using Carbon Aerogels, Environ. Sci. Technol. 36, 30103019.

[17]. C.-M. Yang, W.-H. Choi, B.-K. Na, B.W. Cho, W.I. Cho (2005), Capacitive deionization of $\mathrm{NaCl}$ solution with carbon aerogel-silica gel composite electrodes, Desalination 174, 125-133.

[18]. D.K. Kohli, R. Singh, A. Singh, S. Bhartiya, M.K. Singh, P.K. Gupta (2012), Study of carbon aerogel-activated carbon composite electrodes for capacitive deionization application, Desalination\& Water Treat. 49, 130-135.

[19]. R. Pekala (1989), Organic aerogels from the polycondensation of resorcinol with formaldehyde, J. Mater. Sci. 24, 32213227.

[20]. D. Wu, R. Fu, S. Zhang, M.S. Dresselhaus, G. Dresselhaus (2004), Preparation of lowdensity carbon aerogels by ambient pressure drying, Carbon 42, 2033-2039.
[21]. S.A. Al-Muhtaseb, J.A. Ritter (2003), Preparation and properties of resorcinolformaldehyde organic and carbon gels, Advanced Mater. 15, 101-114.

[22]. G. Qin, S. Guo (2001), Preparation of RF organic aerogels and carbon aerogels by alcoholic sol-gel process, Carbon 39, 1935-1937.

[23]. K.S. Rejitha, P.A. Abraham, N.P.R. Panicker, K.S. Jacob, N.C. Pramanik (2013), Role of Catalyst on the Formation of Resorcinol-Furfural Based Carbon Aerogels and Its Physical Properties, Advanced Nanoparticles. 2, 99-103.

[24]. S.-J. Seo, H. Jeon, J.K. Lee, G.-Y. Kim, D. Park, H. Nojima, J. Lee, S.-H. Moon (2010), Investigation on removal of hardness ions by capacitive deionization (CDI) for water softening applications, Water Res. 44, 2267-2275.

[25]. K.-L. Yang, T.-Y. Ying, S. Yiacoumi, C. Tsouris, E.S. Vittoratos (2001), Electrosorption of ions from aqueous solutions by carbon aerogel: an electrical double-layer model, Langmuir 17, 19611969. 